\title{
Internalization of Cultural Preservation Values Through Traditional Arts in School-Age Children
}

\author{
Elly Kismini ${ }^{1, *}$ Didi Pramono ${ }^{2,}$ Asma Luthfi ${ }^{3,}$ Siti Khuzaimah ${ }^{4}$, Rochayani ${ }^{5,}$ \\ Nur Rahmatul Chasanah ${ }^{6}$
}

\author{
1,2,3,5,6 Dept. of Sociology and Anthropology, Faculty of Social Sciences, Universitas Negeri Semarang, Indonesia \\ ${ }^{4}$ Sekolah Riset Satukata Yogyakarta \\ *Corresponding author. Email: ellykismini@mail.unnes.ac.id
}

\begin{abstract}
Communities have various ways of preserving culture. One of the ways to preserve Javanese traditional arts is to form the Jaran Kepang art community. This article was written based on the results of research conducted in Jetak Hamlet, Duren Village, Bandungan District from January to August 2020. The purpose of this study was to obtain an overview of the efforts of the Jetak Hamlet community to internalize cultural preservation values through traditional Javanese arts in school age children. This study uses a qualitative method. The data collection techniques used in research include: observation, in-depth interviews and documentation. In testing the validity of the data, the authors used triangulation techniques. Data analysis used interactive qualitative data analysis with the following stages: data collection, data reduction, data presentation, and conclusion or verification. The results showed that the community played a role in internalizing the values of cultural preservation through Javanese traditional arts in school age children
\end{abstract}

Keywords: Jaran Kepang dance, Javanese traditional arts, school age children.

\section{INTRODUCTION}

Environmental degradation, globalization and modernization have resulted in the erosion of traditional culture in Indonesian society. This can be seen in almost all aspects of life. Especially those that have been influenced by foreign cultures[1], [2]. Here, we can see how children and teenagers prefer Korean culture. This is due to the large number of Korean dramas on television.

The Indonesian nation has a diverse and high value culture that future generations must preserve. Especially school-aged children who in fact will be the nation's future successors. In several concepts, C. Kluckhohn stated, that culture is a learning process and not something that is inherited biologically. Therefore, culture is a pattern of behavior that is learned and passed down from generation to generation[3].

One of the Indonesian cultures that is still sustainable today is Javanese culture. Javanese culture has a very high value. So, this is very influential on the lives of the people who support it. Art is one of the elements of culture which consists of dance, music, sound art, and so on. Traditional art is an art or culture that needs to be preserved. Traditional arts contain national cultural values that need to be preserved. The process of internalizing cultural values must be started early, especially for children. The goal is that noble values can be properly internalized by every individual in society through socialization, both from within the family and society[4].

Participation from the community is very necessary to preserve traditional arts in the midst of the times. As happened in Jetak Hamlet, Duren Village, Bandungan District, Semarang Regency. This place is one of the areas that has succeeded in maintaining local culture through the Jaran Kepang art in the middle of the development of modern art.

Several previous studies that are relevant include the development of the preservation of Javanese traditional tembang art culture through learning local content in elementary schools, which has positive implications for student personality development [5] [7], while other related research includes[8]-[10]. This research was conducted to reveal the other side of the 
preservation of Javanese culture in school age children.

\section{RESEARCH METHODS}

The method used in this research is qualitative research methods. While the approach used in this research is a case study approach. The focus of this research is the internalization of cultural preservation values through Javanese traditional arts in school age children. This study uses two data sources, namely primary data and secondary data. Primary data were obtained from subjects and research informants. The research subjects were school-age children who were members of the Jaran Kepang art community "Langgeng Mudo Sari". The informants in this study were Jaran Kepang activists. Secondary data were obtained from various sources relevant to the research topic, namely from scientific articles, papers, journal articles from the internet and previous research results related to the research focus under study. Data collection techniques in the form of observation, interviews, and documentation. In testing the validity of the data, this study used triangulation techniques. This study uses a qualitative analysis description technique. According to Miles and Haberman (in Sugiyono, 2015: 337) that qualitative data analysis activities are carried out interactively and continue to completion. This analysis technique is carried out in stages: data collection, data reduction, data presentation, and making conclusions or verification.

\section{RESULT AND DISCUSSION}

Jaran Kepang is a traditional art that is included in the hereditary tradition of the ancestral heritage of the Jetak Hamlet community. Some of the ways that the people of Dusun Jetak internalize the values of cultural preservation through Javanese traditional arts in school-age children include:

\subsection{Registering School-Age Children to the Jaran Kepang Art Community "Langgeng Mudo Sari"}

The Jaran Kepang community "Langgeng Mudo Sari" took the initiative to involve school-age children to take part in preserving traditional arts. In general, there are no specific criteria for school-age children when they want to join this community. Most importantly, children have an interest or interest in Javanese dance. In this community, members who join are also free of charge. Thus, allowing more school age children to join. Art activists usually invite children if there is an invitation to perform. Inviting children to follow the traditional arts of Jaran Kepang is quite easy, because the majority of children have a high interest in these traditional arts. According to Slameto, interest is something that feels like preference and interest in something or activity, without being instructed[11]. Likewise with the interest of school age children in the traditional arts of Jaran Kepang in Jetak Hamlet. There is no element of compulsion for school-age children to join the Jar an Kepang community "Langgeng Mudo Sari".

\subsection{Giving Insight into the Philosophical Values of The Different Types of Dances in the Jaran Kepang Community "Langgeng Mudo Sari"}

In the Jaran Kepang community "Langgeng Mudo Sari", apart from being taught the traditional Jaran Kepang dance, the members are also taught creative dance. Jaran Kepang dance has a deep philosophical meaning. This dance tells the story of a group of gallant warriors on horseback. This dance is a description of the warfare of the ancient Javanese society. The dancers are likened to warriors who fight on the battlefield. Jaran Kepang dance is a sacred dance, so that its implementation is equipped with meaningful rituals. Such as the obligation to fast and prepare offerings before the show. This is done with the intention that the event will run smoothly. However, over time, Jaran Kepang players no longer have to fast, but offerings must still be provided in the form of incense, seven forms of flowers, namely: kantil, jasmine, cananga, red rose, white rose.

Dance is not just a harmony between the forms of movement of the whole body which are arranged according to the rhythm of the gamelan music, but all expressions must contain the "content" of the dance being performed[12]. So if you see a dance work, it is not only seen from its form, but also captures the meaning behind the performance. This is consistent with the essence of dance which is expressed through symbolic and abstract movements.

\subsection{Bringing Trainers from Outside Jetak Hamlet}

To develop the creativity of school age children in dancing. S Elain of coaches coming from senior dancers, the dance community Jaran braid "Lasting Mudo Sari" has also been bringing in trainers from the outside, one of them came from the students of the Faculty of Language and Art (FBS), Semarang State University (UNNES). This is done to increase the knowledge of members of the Jaran Kepang community "Langgeng Mudo Sari", so that they are more confident when performing traditional Javanese dances. Dance training in the form of providing basic motion material. After that, the material from classical to contemporary dance and dance formulation was 
continued. Training is carried out by providing material first. Then every material that has been taught by students, is practiced or imitated by the children who follow the dances in Jetak Hamlet. The trainer consists of one female student and one male student. This kind of training lasts for about 3 years.

\subsection{Parents and Village Government Support}

Most parents of school age children support this artistic activity. Some of them do not support their children who join the Jaran Kepang community "Langgeng Mudo Sari". Parents who are less supportive usually worry that activities at the center will interfere with their child's learning time at school. Meanwhile, parents who support their children joining the Jaran Kepang community can be seen from their role as parents in participating in their children's activities while in the studio. Usually, they accompany the children during rehearsals or performances and help prepare their children's needs. Parents as one of the parties responsible for children's education and have a great influence in supporting children's success. Therefore, parents should provide support for various children's needs, such as protection, comfort, and fulfillment of other life necessities, such as the need to develop an interest in traditional arts. Java.

Apart from support from parents, the Dure $n$ village government also took part in providing support. They provide support in the form of guidance to art groups scattered in various hamlets in Duren Village, including Dusun Jetak. The government also provides maintenance costs for the equipment by submitting a proposal procedure, which will be followed up by the urban village to withdraw the aid.

\section{CONCLUSION}

The people of Dusun Jetak play an active role in the preservation of Javanese traditional arts. This is shown by the formation of the Jaran Kepang art community "Langgeng Mudo Sari" which involves various elements of society including school age children as an effort to internalize cultural values through traditional arts to the younger generation. The efforts made by the people of Jetak Hamlet in internalizing these cultural values include enrolling school-age children in the Jaran Kepang art community "Langgeng Mudo Sari", providing insight into the philosophical values of various types of dances in the Jaran Kepang community "Langgeng Mudo Sari". ", Bringing in trainers from outside the Jetak Hamlet, as well as the support of parents and the village government.

\section{REFERENCES}

[1] N. Carroll, "Art and globalization: Then and now," J. Aesthet. art Crit., vol. 65, no. 1, pp. 131-143, 2007.

[2] E. Tagore-Erwin, "Contemporary Japanese art: between globalization and localization," Arts Mark., 2018.

[3] H. Poerwanto, Kebudayaan dan lingkungan: dalam perspektif antropologi. Pustaka Pelajar, 2000 .

[4] A. Kay, "Art and community development: the role the arts have in regenerating communities," Community Dev. J., vol. 35, no. 4, pp. 414-424, 2000.

[5] E. Kismini, "Pengembangan Konservasi Budaya Kesenian Tradisional Tembang Jawa di Sekolah," in Forum Ilmu Sosial, 2012, vol. 39 , no. 1 .

[6] E. Kismini, "Preservation Of The Local Culture Values Through The Art Of Java Dance In Developing The National Character," in International Conference on Rural Studies in Asia (ICoRSIA 2018), 2019.

[7] T. M. P. Astuti, E. Kismini, and K. B. Prasetyo, "The socialization model of national character education for students in elementary school through comic," Komunitas Int. J. Indones. Soc. Cult., vol. 6, no. 2, pp. 260-270, 2014.

[8] E. T. Murtisari, "Some traditional Javanese values in NSM: From God to social interaction," Int. J. Indones. Stud., vol. 1, no. 1, pp. 110-125, 2013.

[9] W. R. Hapsari, W. Lestari, and S. Sunarto, "Internalization of Character Values of Cèpètan Dance Performance at Manunggal Putra Budaya Group in Karanggayam District Kebumen Regency," Catharsis, vol. 8, no. 2, pp. 206-212, 2019.

[10] E. Kismini, "Eksistensi Budaya Seni Tari Jawa di Tengah Perkembangan Masyarakat Kota Semarang," in Forum Ilmu Sosial, 2013, vol. 40 , no. 1 .

[11] B. Slamet, "Faktor yang mempengaruhinya," Jakarta: Rineka Cipta, 1995.

[12] S. Supriyanti and D. Suharto, "Penciptaan Tari Manggala Kridha sebagai Media Pembentukan Karakter bagi Anak," J. Urban Soc. Arts, vol. 2, no. 1, pp. 18-24, 2015. 